\title{
Three new ginger species (Zingiberaceae) from Laos
}

\author{
J. Leong-Škorničková ${ }^{1}$, O. Šída ${ }^{2}$, S. Bouamanivong ${ }^{3}$, K. Souvannakhoummane ${ }^{4}$, \\ K. Phathavong ${ }^{4}$
}

Key words

Curcuma

gingers

Laos

new species

vulnerable

Zingiber

Zingiberaceae
Abstract Three new Zingiberaceae species from Laos, Curcuma corniculata and C. flammea (Curcuma subg. Ecomata), and Zingiber jiewhoei (Zingiber sect. Zingiber), are described and illustrated here.

Published on 10 October 2014

\section{INTRODUCTION}

Cambodia, Laos and Vietnam comprise one of the least known hotspots of the family Zingiberaceae, the latest comprehensive study being over a century old (Gagnepain 1908). Only Amomum $\mathrm{L}$. has been studied in depth since then, resulting in the description of eleven new species (Lamxay \& Newman 2012). There have been, by contrast, numerous recent descriptions of new species (e.g. Leong-Škorničková \& Lý 2010, Lý et al. 2010, Nguyen \& Leong-Škorničková 2012, Leong-Škorničková \& Trần 2013, Leong-Škorničková et al. 2013, 2014, Leong-Škorničková \& Lưu 2014) and a new genus, Newmania (Leong-Škorničková et al. 2011), from the Indochinese floristic region (sensu Takhtajan 1986), suggesting that a large amount of ginger biodiversity is yet to be documented.

During our extensive explorations of the Indochinese region, the following three ginger species have been found to be new, and are described and illustrated below. The original descriptions and types of all the species in their respective genera/ subgenera have been consulted, especially those from adjacent territories.

While two of these three species are currently known only from their type localities, we believe that detailed descriptions accompanied by colour plates will aid local botanists and students in identification and bring more reports of their distribution in the near future.

The descriptions were made from full-grown, flowering, living material. In line with good practice on collecting Zingiberaceae, the type collections include spirit material and the descriptions are accompanied by detailed photographic documentation. Conservation assessments follow the criteria outlined by IUCN version 3.1. (2012).

\footnotetext{
1 The Herbarium, Singapore Botanic Gardens, National Parks Board, 1 Cluny Road, 259569, Singapore;

corresponding author e-mail: jana skornickova@nparks.gov.sg.

2 Department of Botany, National Museum in Prague, Cirkusová 1740, Praha 9 - Horní Počernice 190 00, Czech Republic.

${ }^{3}$ Biotechnology and Ecology Institute, Ministry of Science and Technology, Vientienne, Lao P.D.R.

${ }^{4}$ Pha Tad Ke Botanical Garden, Ban Wat That, P.O. Box 959, 06000 Luang Prabang, Lao P.D.R.
}

\section{TAXONOMIC TREATMENT}

Curcuma corniculata Škorničk., sp. nov. — Fig. 1

Similar to Curcuma glans K.Larsen \& Mood, but differs in the red corolla lobes (vs white or white with a reddish tinge), bright orange, diamond-shaped labellum with horn-like tips curving outwards (vs obovate white labellum with golden yellow median band and apex) and bright orange lateral staminodes with dark purple patch at the base (vs white lateral staminodes with purple base and golden yellow apex). — Type: Jana Leong-Škorničková, Trần Hú́u Đăng, Otakar Šída, Udone Souvannakhoummane \& Kittisack Phoutthavong JLS-1752 (holotype SING (incl. spirit); isotype E, HNL, P), Laos, Louangphrabang, Ban Long Lao Mai, 866 m asl, N1945'16.6" E10202'56.7", 20 June 2012.

Etymology. The specific epithet 'corniculata' is derived from Latin and means small horns, in reference to the horn-like tips of the labellum.

Herb to $1 \mathrm{~m}$ tall. Rhizome ovoid, c. $1.5-3.5$ by $0.8-1.5 \mathrm{~cm}$, with thin branches (c. 3-6 mm diam), brown externally, light yellow internally, slightly aromatic; root tubers elliptic, $3-5.5 \mathrm{~cm}$ long, light brown externally, pure white internally with translucent white centre, distanced $5-15 \mathrm{~cm}$ from rhizome. Leafy shoot with 5-9 leaves when flowering; pseudostem to $35 \mathrm{~cm}$ long, green, composed of leaf sheaths; leafless sheaths perhaps two, decayed at anthesis; leaf sheaths green, puberulent; ligule 5-11 mm long, bilobed, hyaline, greenish white, translucent, puberulent; petiole $10-35 \mathrm{~cm}$ long (petiole of first leaf shortest, innermost leaves longer), canaliculate, green, shortly sparsely hairy; lamina broadly elliptic to elliptic-ovate, to 47 by $22 \mathrm{~cm}$, prominently plicate, adaxially bright green, sparsely shortly hairy along main veins, abaxially lighter green, glabrous; midrib glabrous, green; base cordate; apex acute, c. 1-1.5 cm long, puberulent. Inflorescence lateral, many-flowered; peduncle $4-15 \mathrm{~cm}$ long, to $1 \mathrm{~cm}$ diam, cream-white, with up to 5 sheathing bracts (mostly decayed, $1-8 \mathrm{~cm}$ long); spike 7-11 cm long, c. 4-6 cm diam in the middle, without coma; fertile bracts 20-30 per inflorescence, bract $3-6$ by $1.2-3.3 \mathrm{~cm}$ (larger at the base of the inflorescence), ovate to trullate, smaller and ovate at the apex, whitish at base to light green at apex with various degrees of red tinge throughout the bract (resulting in light red to deep red bracts, colour varying within population), both surfaces shortly pubescent, connate in the lower $1 / 2$ to $1 / 4$; enclosing cincinnus with 3 flowers at the base of the inflorescence, 1-2 

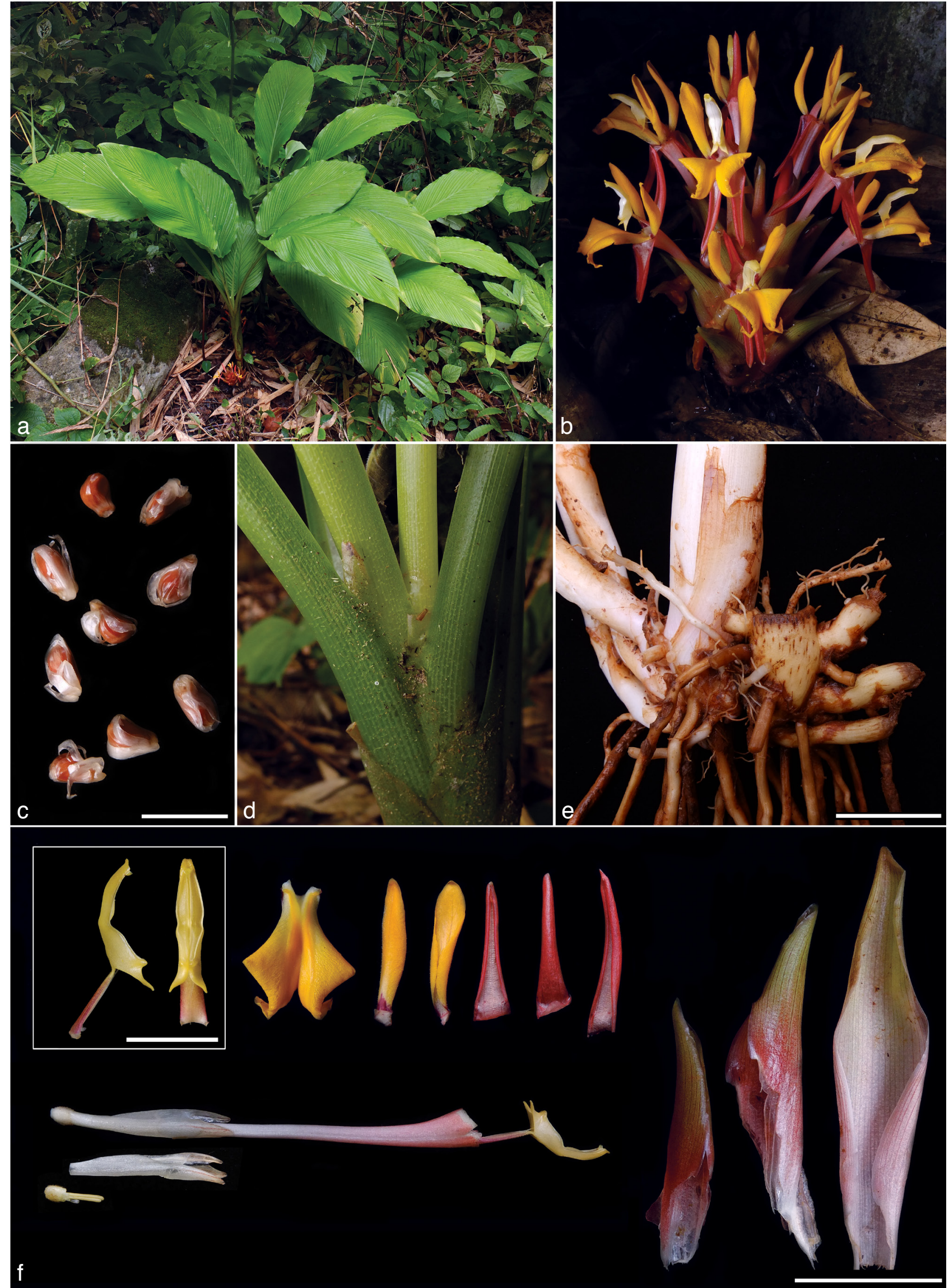

Fig. 1 Curcuma corniculata Škorničk. a. Habit; b. inflorescence; c. seeds; d. ligules; e. rhizome; f. flower dissection, with detail of stamen from side and front view (all from type: $J L S-1752$ ). - Scale bars: $\mathrm{c}, \mathrm{f}$ (inset) $=1 \mathrm{~cm} ; \mathrm{e}, \mathrm{f}=2 \mathrm{~cm}$. - Photos by Jana Leong-Škorničková. 
flowers at the top; bracteoles much reduced, one per flower, ovate, boat-shaped, c. $1-2.5 \mathrm{~mm}$ by c. $1 \mathrm{~mm}$ (outer ones larger, inner ones gradually smaller), hyaline, translucent white, glabrous. Flowers $6.5-8 \mathrm{~cm}$, much exserted from the bracts; calyx to $21 \mathrm{~mm}$ long, 3-toothed, unilaterally split to c. $6-8 \mathrm{~mm}$, translucent white or with slight red tinge at upper part, sparsely hairy or glabrous; floral tube c. $4-5.5 \mathrm{~cm}$ long, externally white at the base, with red tinge at the apex, densely puberulent, internally white, sparsely puberulent with dorsally placed groove holding the style; dorsal corolla lobe $22-27$ by $7-9 \mathrm{~mm}$, triangular ovate, concave, with sides rolled inwards, glabrous, red outside, light red to white inside, apex mucronate, mucro c. $2 \mathrm{~mm}$, with a few short hairs; lateral corolla lobes $21-24$ by $7-8 \mathrm{~mm}$, triangular ovate with sides incurved, concave, glabrous, red outside, light red to white inside; labellum $23-25$ by $16-20 \mathrm{~mm}$, diamond-shaped, margins recurved, apex bifid with an incision up to $14 \mathrm{~mm}$ long and strongly recurved horn-like lobes, base of the labellum light orange with two orange lines in the centre and often with slight purple tinge laterally, middle and apex of the labellum light to deep orange at the margin, with deep orange band running through the centre (median band); lateral staminodes c. $22-24$ by $8-10 \mathrm{~mm}$, slightly rhomboid with sides flexing outwards, bright orange with $3-4 \mathrm{~mm}$ at base tinged dark purple (sometimes missing), sparse, short glandular hairs present on both surfaces. Stamen $18-20 \mathrm{~mm}$; filament $8-9 \mathrm{~mm}$ long, white with purple tinge towards base, $2.5-3 \mathrm{~mm}$ broad at base, $1.5 \mathrm{~mm}$ broad at apex (the point of attachment to the connective), covered with dense, very short, glandular hairs; anther c. 13-15 mm long, spurred, connective light yellow to very light orange, densely covered with short glandular hairs; anther spurs c. $3 \mathrm{~mm}$ long, triangular with sharp tips, pointing outwards; anther crest thin, rounded, c. $1.5 \mathrm{~mm}$ long and c. $1 \mathrm{~mm}$ broad at base, orange; anther thecae 9-11 mm long, dehiscing along their whole length. Epigynous glands 2, c. 4-6 mm long, $0.3-0.5 \mathrm{~mm}$ diam, cream-white. Style thin, white, glabrous, held in groove in dorsal side of floral tube; stigma c. $1 \mathrm{~mm}$ long, 0.8 $\mathrm{mm}$ wide, white, ostiole ciliate, facing upwards. Ovary $2-3$ by 2-2.5 mm, trilocular, densely puberulent, hairs c. $0.2 \mathrm{~mm}$ long. Fruit a globose trilocular capsule, c. $1 \mathrm{~cm}$ diam, white, puberulous; seeds irregularly obovoid, 4-7 mm long, light brown, shiny, enclosed in translucent white, laciniate aril. Description based on living and spirit material of JLS-1752.

Distribution - Endemic to Laos, currently known only from the type locality.

Habitat \& Ecology - Growing in bamboo vegetation on limestone outcrops, at 800-900 $\mathrm{m}$ asl.

Phenology - Flowering in early rainy season, end May to July, flowers last a single day, open in the morning and closing in late afternoon. Fruiting June to July (August?).

Conservation status - Specimen records exist so far only from the type locality. Local people who were interviewed and shown images of this species, reported that it occurs in various areas adjacent to Louangphrabang. The number and size of the populations are, however, not yet exactly known. Most Curcuma species in subg. Ecomata, especially those allied to C. bicolor Mood \& K.Larsen, where this species belongs, tend to be fairly restricted in their distribution. Accordingly, we estimate that the extent of occurrence is less than $20000 \mathrm{~km}^{2}$. The type population is not in a protected area and is used for cultivation of maize (Zea mays L.), groundnuts (Arachis hypogaea L.) and other crops, therefore continuing decline in area, extent and quality of habitat can be foreseen. Category Vulnerable VU $\mathrm{B} 1 \mathrm{ab}$ (iii) is, with caution, proposed here. Further exploration of the region is needed as this species may be Endangered or Critically Endangered soon.

Notes - Curcuma corniculata belongs to the recently established subg. Ecomata (Záveská et al. 2012). The two most closely related species in this subgenus are C. glans and C. bicolor. It may be fairly difficult to determine dried herbarium specimens but there is no confusion when living, flowering material is available (see Mood \& Larsen 2001) or when there are appropriate notes or photographs accompanying specimens. Also, if a spirit specimen is present, confusion is not likely. Among these species, $C$. corniculata can be readily recognised by its bifid labellum, with the two strongly reflexed horn-like lobes.

\section{Curcuma flammea Škorničk., sp. nov. - Fig. 2}

Similar to Curcuma bicolor Mood \& K.Larsen, but differs in inflorescence with longer peduncles to $13 \mathrm{~cm}$ long (vs almost sessile inflorescence with peduncle c. $1.5 \mathrm{~cm}$ long), bracts white, pink to dark red (vs light green bracts with more or less reddish tinge and prominent veins), bright orange labellum with various degree of red ornamentation (vs mostly yellow-orange labellum with reddish to purple margins). - Type: Jana Leong-Škorničková, Trần Hû́u Đăng, Somsanith Bouamanivong, Khantheo Santhammavong, Udone Souvannakhoummane, Kittisack Phoutthavong JLS-1777 (holotype SING (incl. spirit); isotype E, HNL, P), Laos, Vientiane Prov., Vang Vieng Dist., Ban Phou Din Deng, 467 m asl, N1857'43.2" E102²6'09.9", 23 June 2012.

Etymology. The specific epithet is Latin for fiery or flaming. It is given on account of the bright orange-red colours of the flowers and bracts, which resemble flames on the forest floor when in full bloom.

Herb to $70 \mathrm{~cm}$ tall. Rhizome ovoid, c. $1-1.5$ by $0.8-1.2 \mathrm{~cm}$, with thin branches c. 3-6 mm diam, brown externally, light yellow internally, slightly aromatic with bitter smell; root tubers elliptic, c. 3.5 by $2 \mathrm{~cm}$, light brown externally, pure white internally with translucent white centre, distanced $5-15 \mathrm{~cm}$ from rhizome. Leafy shoot to $90 \mathrm{~cm}$ long with 1-5 leaves when flowering; pseudostem to $30 \mathrm{~cm}$ long, composed of leaf sheaths; leafless sheaths decayed at anthesis; leaf sheaths white green or with pink tinge at base turning green towards the apex, densely puberulent; ligule 3-5 mm long, bilobed, lobes round, hyaline, greenish white, translucent, hairy; petiole 6-27 cm long (petiole of first leaf shortest, innermost leaves longer), canaliculate, green, densely puberulent; lamina elliptic, broadly elliptic to elliptic-ovate, to 36 by $17 \mathrm{~cm}$, prominently plicate, adaxially bright green, shortly hairy along main veins, abaxially lighter green, shortly puberulent; midrib glabrous, green; base cordate; apex acute, c. 5-10 mm long. Inflorescence central (often breaking through the pseudostem) or rarely lateral (both can occur on the same plant), many-flowered; peduncle $3-13 \mathrm{~cm}$ long, to $7 \mathrm{~mm}$ diam, cream-white; spike $4-9 \mathrm{~cm}$ long, c. $3 \mathrm{~cm}$ diam in the middle, without coma; fertile bracts 7-24 per inflorescence, $3-6$ by $1.2-3.3 \mathrm{~cm}$ (larger at the base of the inflorescence), ovate to trullate, smaller and ovate at the apex, whitish to light green at base with various degree of red tinge throughout the bract (resulting in very light pink, light red to deep red bracts; the colour of the bracts is consistent within a spike, but varies within a population), very sparsely puberulent outside, glabrous inside, connate in the lower $1 / 2$ to $1 / 3$; enclosing cincinni with 3 flowers at the base of the inflorescence, 1-2 flowers at the top; bracteoles strongly reduced, one per flower, ovate, boatshaped, c. 1-2 by c. $1 \mathrm{~mm}$ (outer ones larger, inner ones gradually smaller or totally absent), hyaline, translucent white, glabrous. Flowers $6.5-7.5 \mathrm{~cm}$, much exserted from the bracts; calyx to $22 \mathrm{~mm}$ long, 3-toothed, unilaterally split c. 8-10 mm, translucent white with more or less red tinge especially distally, sparsely puberulent; floral tube c. $4-5 \mathrm{~cm}$ long, externally white at the base, with rich red tinge at the apex, densely puberulent, internally white to very light orange, puberulent with dorsally placed groove holding the style; dorsal corolla lobe 22-25 by 9-11 mm, triangular ovate, concave, with sides rolled inwards, glabrous, red outside, light red inside, apex mucronate, mucro c. $2 \mathrm{~mm}$; lateral corolla lobes $20-21$ by $8-9 \mathrm{~mm}$, triangular ovate with sides rolled inwards, concave, glabrous, red on outside, 

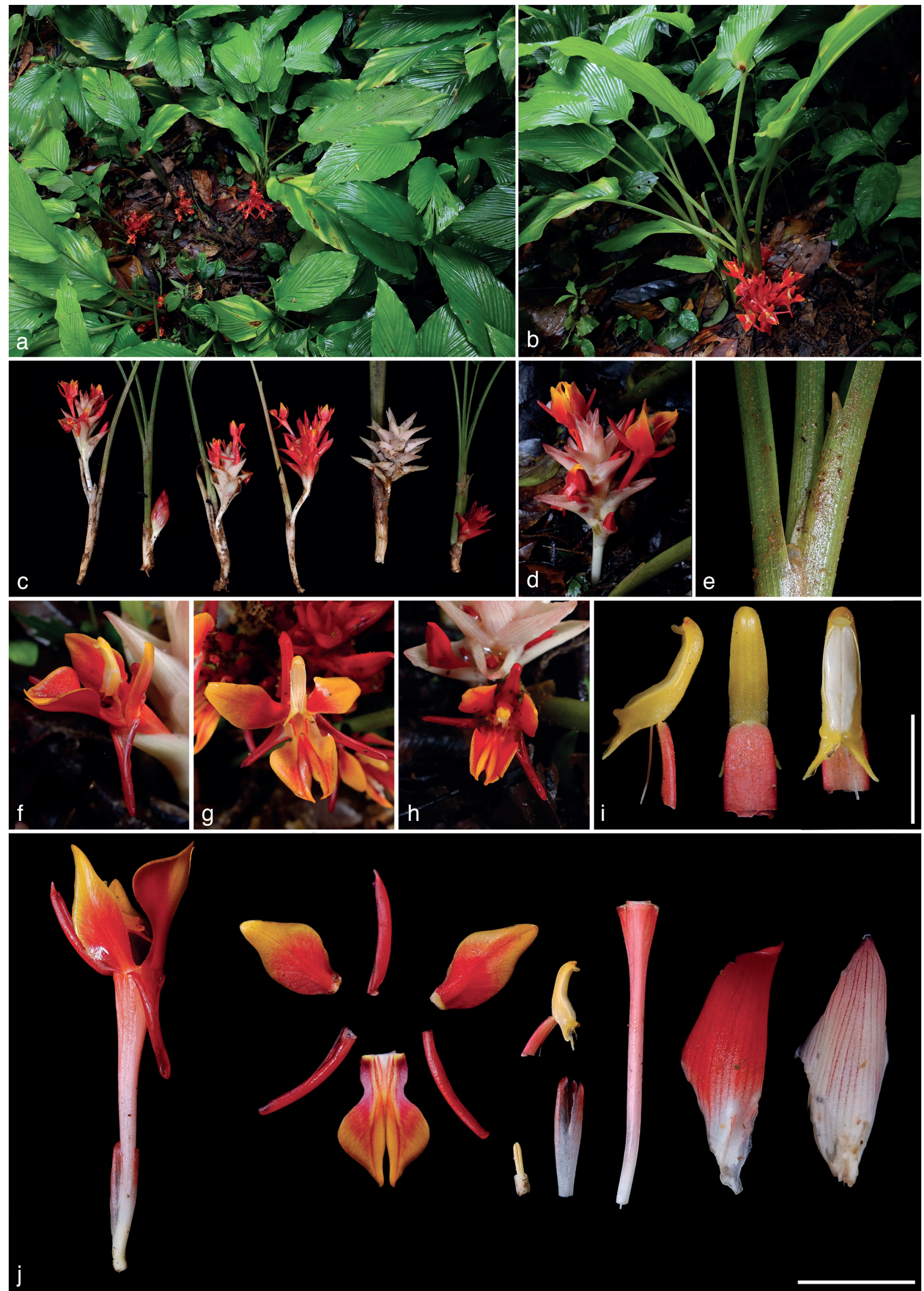

Fig. 2 Curcuma flammea Škorničk. a, b. Habit; c, d. inflorescences; e. ligules; f-h. flower (side view, front view, top view); i. detail of stamen (side, back and front view); j. flower dissection (all from type: JLS-1777). — Scale bars: $i=1 \mathrm{~cm} ; j=2 \mathrm{~cm}$. — Photos by Jana Leong-Škorničková. 
light red on inside; labellum 21-25 mm long, 7-9 mm broad at basal $1 / 3$, then diamond-shaped in distal $2 / 3$, c. $16-21 \mathrm{~mm}$ at widest point, apex bifid with an incision to $8 \mathrm{~mm}$ long, base of the labellum light orange with dark red lines, middle and apical part of the labellum orange at apex and margin, with dark red tinge towards the lower part, with deep orange band marked with dark red line on the outside running through the centre (median band); lateral staminodes $20-22$ by $10-13 \mathrm{~mm}$, rhomboid, bright red in basal half, orange at apex, glabrous outside, with short glandular hairs present on the middle part facing the centre of the flower. Stamen 16-17 mm long; filament 7-8 mm long, orange with red tinge, $4 \mathrm{~mm}$ broad at base, $2 \mathrm{~mm}$ broad at apex (the point of attachment to the connective), covered with glandular hairs; antherc. $14 \mathrm{~mm}$ long, spurred, connective light orange, densely covered with short glandular hairs; anther spurs 3-4 mm long, narrowly triangular with sharp tips pointing outwards; anther crest thick, rounded, c. $1.5 \mathrm{~mm}$ long and c. $2 \mathrm{~mm}$ broad at base, orange; anther thecae 9-10 mm, dehiscing along their entire length. Epigynous glands 2, c. 5-6 mm long, c. $0.6 \mathrm{~mm}$ diam, light yellow at base, darker at apex. Style thin, white, glabrous, placed in a groove in dorsal side of floral tube; stigma c. $1.5 \mathrm{~mm}$ long, $1.5 \mathrm{~mm}$ wide, white, ostiole ciliate, facing upwards. Ovary $2-3$ by $2-2.5 \mathrm{~mm}$, trilocular, densely hairy, hairs c. $0.2 \mathrm{~mm}$ long. Fruits not seen. Description based on living and spirit material of Leong-Škorničková et al. JLS-1777.

Distribution - Currently known only from the type locality.

Habitat \& Ecology - Growing on steep limestone slopes covered with primary dipterocarp forest at $400-500 \mathrm{~m}$ asl.

Phenology - Flowering in the early rainy season, end May to July, flowers last a single day, open in the morning and closing in late afternoon. Fruiting June to July (August?).

Conservation status - Specimen records exist so far only from the type locality. Most Curcuma species in subg. Ecomata, especially from the alliance of $C$. bicolor, where this species belongs, tend to be fairly restricted in distribution. Accordingly, we estimate that the extent of occurrence is less than $20000 \mathrm{~km}^{2}$. While the habitat of this species is unsuitable for fast agricultural exploitation, the fact that Vang Vieng is a popular tourist destination and the type population is not in a protected area, continuing decline in area, extent and quality of habitat can be foreseen. Category Vulnerable VU B1ab(iii) is therefore proposed here. Further exploration of the area around Vang Vieng is needed to understand the situation better and amend the conservation status.

Notes - Curcuma flammea also belongs to subg. Ecomata. Morphologically, the most similar species are C. bicolor and C. rhomba Mood \& K.Larsen. Preliminary molecular analyses of subg. Ecomata (Záveská et al. unpubl.) suggest that $C$. flammea is closer to C. bicolor than to C. rhomba.

\section{Zingiber jiewhoei Škorničk. sp. nov. - Fig. 3}

Similar to Zingiber peninsulare Theilade, but differs in cream-white labellum and cream-white staminodes with dense, bright, purple-violet blotches (vs labellum and staminodes dark purple with white spots). - Type: Jana Leong-Škorničková, Trần Hû́u Đăng, Somsanith Bouamanivong, Khantheo Santhammavong, Udone Souvannakhoummane, Kittisack Phoutthavong JLS-1807 (holotype SING (incl. spirit); isotype E, HNL), Laos, Vientiane Prov., Vang Vieng Dist., Kaeng Nyui waterfall, $370 \mathrm{~m}$ asl, N1857'21.5" E102²9'45.5", 25 June 2012.

Etymology. We name this beautiful species in honour of Mr. Tan Jiew Hoe, President of the Singapore Gardening Society, for his continuous contributions towards ginger research at Singapore Botanic Gardens and generous support of plant taxonomy in Laos.

Rhizomatous, clump-forming herb. Rhizome 1-3cm diam, branched, $1-3 \mathrm{~cm}$ between leafy shoots arising from the same rhizome, externally pinkish (young rhizomes) to light brown (older rhizomes), internally purple, smelling strongly of lemongrass, scales broadly triangular, soon decaying. Leafy shoot to $2.5 \mathrm{~m}$ long, arching, with up to 42 leaves, base swollen to $3 \mathrm{~cm}$ diam, pink-red, basal $1 / 2$ to $1 / 3$ of pseudostem leafless, sheathed by numerous (c. 13) leafless sheaths; leafless sheaths dark green with faint, dark red-brown tinge towards base; leaf sheaths green, glabrous at base, pubescent towards the ligule; ligule to $9 \mathrm{~mm}$ long, shallowly bilobed, green, pubescent when young, glabrescent in old pseudostems; petiole reduced to a pulvinus (to $5 \mathrm{~mm}$ long); lamina to $30 \times 8 \mathrm{~cm}$ (gradually smaller towards apex of leafy shoot), narrowly ovate (lanceolate), gradually tapering to attenuate apex, base rounded, adaxially glossy green, glabrous, abaxially lighter green and sparsely villose. Inflorescence radical, on erect peduncle to $16 \mathrm{~cm}$ long sheathed by $4-8$ sterile bracts; spike $9-18$ by $4-5 \mathrm{~cm}$, fusiform, with up to 50 bracts; bracts obovate, to 4.7 by $2.7 \mathrm{~cm}$ (smaller towards apex of inflorescence), apex broadly acute, externally bright red, whitish towards base, internally whitish except red margins, glabrous and glossy both sides, enclosing a single flower; bracteole to $4 \mathrm{~cm}$ long, $15 \mathrm{~mm}$ broad at widest point, narrowly ovate, translucent white with apex tinged red, glabrous throughout. Flowers $7-9 \mathrm{~cm}$ long; calyx c. $21 \mathrm{~mm}$ long, translucent white, glabrous, with three inconspicuous, reddish teeth at apex, with unilateral incision c. $10 \mathrm{~mm}$; floral tube c. $42 \mathrm{~mm}$ long, white towards base, cream-yellow towards apex, externally glabrous, internally shortly puberulous at apex; dorsal corolla lobe narrowly ovate-triangular, to $40 \mathrm{~mm}$ long, c. $11 \mathrm{~mm}$ broad at widest point, semi-translucent light yellow, glabrous throughout, apex mucronate, mucro < $1 \mathrm{~mm}$; lateral corolla lobes narrowly ovate-triangular, to $35 \mathrm{~mm}$ long, 5-6 mm broad at widest point, semi-translucent light yellow, glabrous throughout, apex acute; labellum c. $30 \mathrm{~mm}$ long, c. $16 \mathrm{~mm}$ wide (c. $28 \mathrm{~mm}$ including the staminodes), ovate, cream-white; lateral staminodes $16-20 \mathrm{~mm}$ long, c. $7 \mathrm{~mm}$ broad, more or less elliptic, connate to the labellum by basal $2 / 3$, cream-white with dense bright purple-violet blotches. Stamen $25 \mathrm{~mm}$ long; filament reduced to $<1 \mathrm{~mm}$; anther c. $25 \mathrm{~mm}$ long (crest not straightened), c. $4 \mathrm{~mm}$ broad, connective tissue cream-white with pink tinge, glabrous; anther crest c. $20 \mathrm{~mm}$ long (straightened), wrapped around stigma, white, glabrous; anther thecae c. $14 \mathrm{~mm}$ long, dehiscing along their entire length. Epigynous glands 2, c. $5 \mathrm{~mm}$ long, c. $0.75 \mathrm{~mm}$ diam, ochraceous. Style white, glabrous; stigma 2-3 mm long, slightly thicker than style, white, ostiole facing downwards (towards the labellum), ciliate. Ovary 4.5 by $3 \mathrm{~mm}$, white, glabrous, trilocular with central placentation. Fruit (young fruit, perhaps immature) ovoid or slightly trigonal capsule, 2.3 by $1.1 \mathrm{~cm}$, white, glabrous; seeds c. 8 by $3 \mathrm{~mm}$, dark maroon, enclosed in translucent white, irregularly laciniate aril. Description based on living and spirit material of Leong-Škorničková et al. JLS-1807.

Distribution - Currently known only from the type locality.

Habitat \& Ecology - Growing near streams in lowland deciduous forest.

Phenology - Flowering in the early rainy season, June to July, flowers open in the afternoon, around $3 \mathrm{pm}$ and close the next morning. Fruiting occurs at the end of June to August.

Conservation status - Specimen records exist so far only from the type locality. Accordingly, we conclude that the extent of occurrence is less than $20000 \mathrm{~km}^{2}$. The type locality is a popular tourist destination and the type population is not in a protected area, continuing decline in area, extent and quality of habitat can be foreseen. Category Vulnerable VU B1a,b(iii) is therefore proposed here. Further exploration of the area around Vang Vieng is needed to understand the situation better and to amend the conservation status.

Notes - By its fusiform inflorescences and bright red bracts, $Z$. jiewhoei resembles Z. peninsulare and Z. newmanii Theilade 

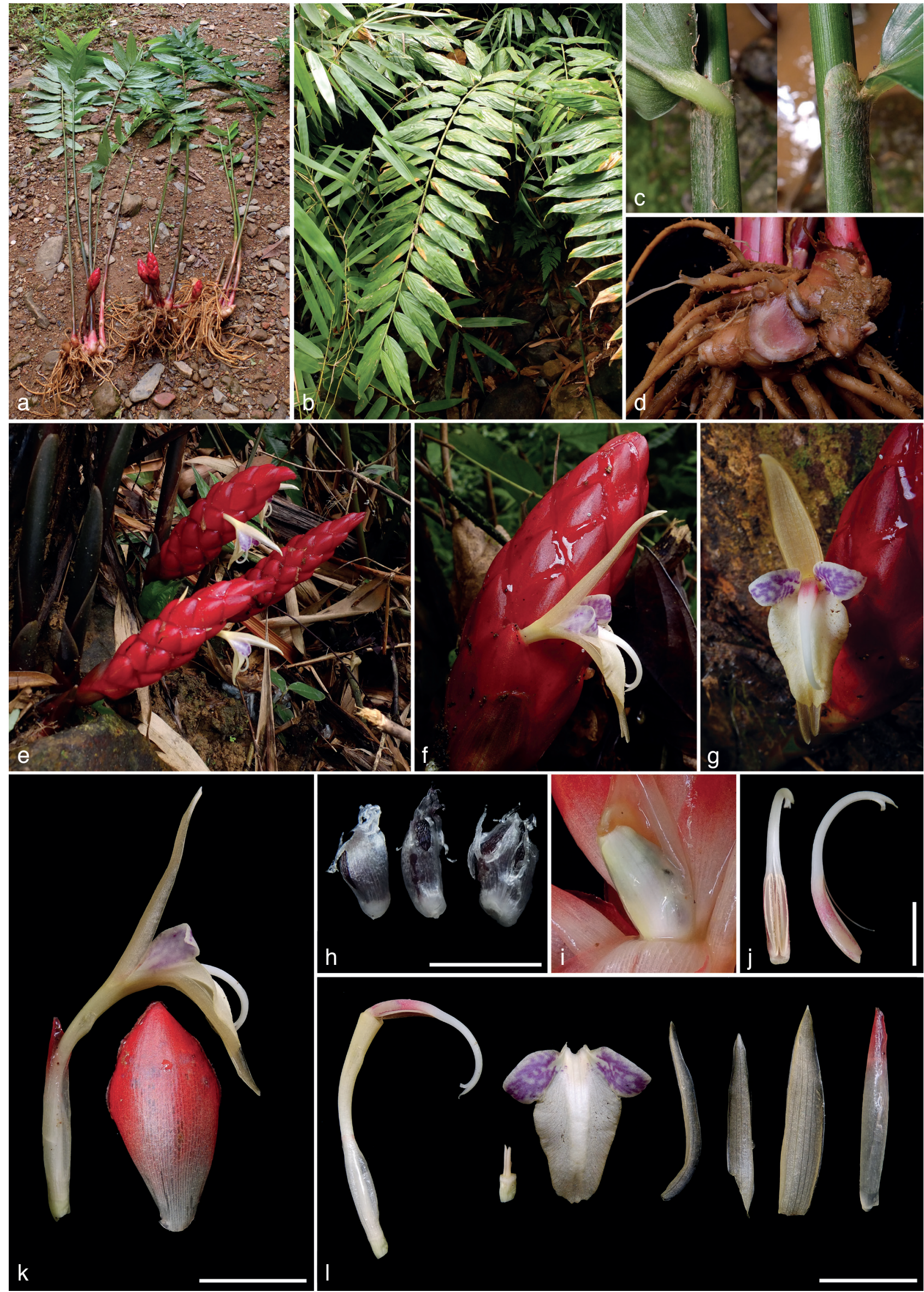

Fig. 3 Zingiber jiewhoei Škorničk. a, b. Habit; c. detail of pulvinus and ligule; d. internal colour of rhizome; e. inflorescence; f. flower (side view); g. flower (front view); h. seeds; i. young fruit in bract; j. stamen (front and side view); k. fertile bract and flower with bracteole (side view); I. dissected flower (all from type: JLS-1807). — Scale bars: $\mathrm{h}, \mathrm{j}=1 \mathrm{~cm} ; \mathrm{k}, \mathrm{I}=2 \mathrm{~cm}$. — Photos by Jana Leong-Škorničková. 
but it can be readily recognised by its cream-white labellum and cream-white staminodes with dense bright purple-violet blotches (vs labellum and staminodes with dense dark-maroon blotches).

Acknowledgements We thank the curators of BK, BKF, E, HN, K, P, SING, and VNM for letting us examine specimens in their care, the Asian Zingiberaceae Information Centre at Singapore Botanic Gardens, and the Zingiberaceae Resource Centre at the Royal Botanic Garden Edinburgh (http:// elmer.rbge.org.uk/ZRC/) for providing protologues and related references. We are grateful to Rik Gadella, Director of Pha Tad Ke Botanic Garden, and Dr. Sourioudong Sundara, Director Biotechnology and Ecology Institute, Ministry of Science and Technology, for their solid support during our fieldwork in Laos. We also thank Trần Hứu Đăng, Somdi Oudomsack and Lee Vue for their assistance in the field. Funding by the National Parks Board (Singapore), and by the Czech Science Foundation (GAČR 14-13541S) is gratefully acknowledged. Further funding was kindly provided by the Ministry of Culture of the Czech Republic (DKRVO 2013/10, National Museum, 00023272). The two reviewers are acknowledged for their constructive comments and language improvements of this manuscript.

\section{REFERENCES}

Gagnepain F. 1908. Zingibéracées. In: Lecomte H (ed), Flore Générale de l'Indo-Chine, vol. 6: 25-121. Masson \& Co., Paris.

IUCN. 2012. IUCN Red List Categories and Criteria: v. 3.1. 2nd ed. Gland, Switzerland; Cambridge, UK.

Lamxay V, Newman MF. 2012. A revision of Amomum (Zingiberaceae) in Cambodia, Laos and Vietnam. Edinburgh Journal of Botany 69, 1: 99-206. Leong-Škorničková J, Lưu HT. 2014. Curcuma leonidii, a new species from southern Vietnam. Phytotaxa 126, 1: 37-42.

Leong-Škorničková J, Lý NS. 2010. Curcuma pambrosima sp. nov. (Zingiberaceae) from central Vietnam. Nordic Journal of Botany 28: 652-655.

Leong-Škorničková J, Lý NS, Poulsen AD, et al. 2011. Newmania: A new ginger genus from central Vietnam. Taxon 60: 1386-1396.

Leong-Škorničková J, Šída O, Trần HĐ. 2013. Curcuma pygmaea sp. nov. (Zingiberaceae) from Vietnam and notes on two related species $\mathrm{C}$. parviflora and C. thorelii. Nordic Journal of Botany 31: 639-647.

Leong-Škorničková J, Trần HĐ. 2013. Two new species of Curcuma subgen. Ecomata (Zingiberaceae) from southern Vietnam. Gardens' Bulletin Singapore 65: 169-180.

Leong-Škorničková J, Trần HĐ, Nguyễn QB, et al. 2014. Siliquamomum alcicorne (Zingiberaceae: Alpinioideae), a new species from central Vietnam. Gardens' Bulletin Singapore 66: 39-46.

Lý NS, Hul S, Leong-Škorničková J. 2010. Siliquamomum oreodoxa (Zingiberaceae): A new species from Southern Vietnam. Gardens' Bulletin Singapore 61: 359-367.

Mood J, Larsen K. 2001. New curcumas from South-eastAsia. The New Plantsman 8: 207-217.

Nguyễn QB, Leong-Škorničková J. 2012. Distichochlamys benenica (Zingiberaceae), a new species from Vietnam. Gardens' Bulletin Singapore 64: 195-200.

Takhtajan A. 1986. Floristic regions of the world. Berkeley, University of California Press.

Záveská E, Fér T, Šída O, et al. 2012. Phylogeny of Curcuma (Zingiberaceae) based on plastid and nuclear sequences: Proposal of the new subgenus Ecomata. Taxon 61: 747-763. 